\title{
Mating system of a Neotropical roost-making bat: the white-throated, round-eared bat, Lophostoma silvicolum (Chiroptera: Phyllostomidae)
}

Received: 30 July 2004 / Revised: 15 November 2004 / Accepted: 10 January 2005 / Published online: 9 March 2005

(C) Springer-Verlag 2005

\begin{abstract}
The vast majority of bats strongly depend on, but do not make, shelters or roosts. We investigated Lophostoma silvicolum, which roosts in active termite nests excavated by the bats themselves, to study the relationship between roost choice and mating systems. Due to the hardness of the termite nests, roost-making is probably costly in terms of time and energy for these bats. Video-observations and capture data showed that single males excavate nests. Only males in good physical condition attracted females to the resulting roosts. Almost all groups captured from excavated nests were single male-multifemale associations, suggesting a harem structure. Paternity assignments based on ten polymorphic microsatellites, revealed a high reproductive success of $46 \%$ by nest-holding males. We suggest that the mating system of L. silvicolum is based on a resource-defense polygyny. The temperatures in the excavated nests are warm and stable, and might provide a suitable shelter for reproductive females. Reproductive success achieved by harem males appears to justify the time and effort required to excavate the nests. Reproductive success may thus have selected on an external male phenotype, the excavated nests, and have contributed to the evolution of an otherwise rare behavior in bats.
\end{abstract}

Communicated by G. Wilkinson

D. K. N. Dechmann $(\bowtie) \cdot$ B. König · G. Kerth Zoologisches Institut, Universität Zürich-Irchel, Winterthurerstrasse 190,

8057 Zürich, Switzerland

e-mail: dechmann@zool.unizh.ch

Tel.: +41-1-6355281

Fax: +41-1-6355490

D. K. N. Dechmann · E. K. V. Kalko

Experimental Ecology, University of Ulm,

Albert-Einstein Allee 11,

89069 Ulm, Germany

E. K. V. Kalko

Smithsonian Tropical Research Institute,

P.O. Box 2072, Balboa, Panama
Keywords Reproductive cycle - Reproductive success · Resource-defense polygyny $\cdot$ Lophostoma silvicolum . Post-partum estrus

\section{Introduction}

Animals often depend on nests or other protected shelters for survival and successful reproduction, and many species must invest time and effort to build, maintain, and/or defend shelters (Collias 1964; Morrison and Morrison 1981). Consequently, the making of shelters is an important investment in reproduction and individual fitness. When females are capable of rearing young alone, it is usually not in the males' interest to invest by contributing to parental care. In this case, females must construct shelters alone and thus interact with males only to mate (Dawkins 1976; Hansell 1984). However, a male may share parental care or provide other services, if it keeps the females close and he thus gains biased access to matings. Shelter-making can also be a form of extended male phenotype, enabling females to judge the quality of potential mates (Dawkins 1999). In many terrestrial vertebrates, males compete for females, while the latter choose their mating partners. Females might then mate with a male only once he has proven himself suitable, e.g. by completing a shelter (Andersson 1994). Knowing the identity of individuals contributing to the building of shelters may help to understand the relationship between this behavior and a species' mating system.

The importance of shelters is particularly evident in the large and diverse order of bats. Most bat species strongly depend on roosts, in which they spend the day and often a large proportion of the night (Kunz 1982). Nonetheless, only about 20 of the more than 1,100 species are known or suspected to make their own roosts (reviewed in Kunz and Lumsden 2003). Individuals working on roosts have been observed in even fewer species. Single males of the short-nosed fruit bat, Cynopterus sphinx, make so-called tents by chewing on the stems of vines or trees (Balasingh et al. 1995). Similar behavior has been inferred in other 


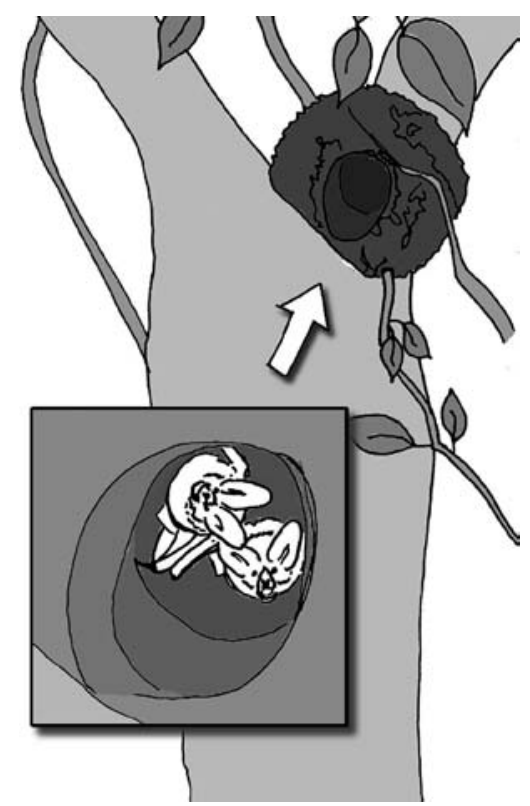

Fig. 1 A termite nest with a bat-made cavity. Insert: close-up of cavity containing two bats

bat species from bite marks on leaves or on flower and fruit stems (Bhat and Kunz 1995; Storz and Kunz 1999), and from manipulated arboreal ant and termite nests (Hodgkison et al. 2003). The Neotropical Lophostoma silvicolum belongs to the family Phyllostomidae, which includes the majority of roost-making bats. This species excavates active arboreal nests of the termite Nasutitermes corniger (Fig. 1; Kalko et al., unpublished work). The sex and social context of roost-making individuals in this, as in most other roost-making species, were unknown.

The construction of cavities in the nests of social insects occurs in many avian families (Collias 1964). In contrast, among bats it is known only in the genus Lophostoma, three species of flying foxes, and possibly a vespertilionid bat (Kunz and Lumsden 2003). The termite nests that $L$. silvicolum excavates are made of hard pre-digested wood, mixed with fecal material (Dietz and Snyder 1924). Consequently, both excavation and maintenance of cavities are assumed to be costly.

We hypothesized that single males are responsible for the making of roosts. Generally, roost-making, as a form of parental care (Kunz and Hood 2000), can be provided by either or both parents. In contrast, as a form of advertisement or a direct service to attract mating partners, it is usually provided by the males (Kleiman and Malcolm 1981). Consequently, males and females would be differently motivated to contribute to roost-making, depending on the species' mating system. Most roost-making bats are assumed or known to live in single male-multifemale groups, called harems (Kunz and Lumsden 2003). As harems are often an indicator of resource or female defense polygyny in mammals, we expected a similar group structure in our study species (Clutton-Brock 1989). Based on this hypothesis and on the assumption that the excavation of nests is costly, we tested the following predictions: (a) only males excavate termite nests, (b) excavating males are in better condition than non-excavating males, (c) there is only one reproductively active, adult male per nest, (d) reproductive success of males is higher with females roosting in their nest than with females in other nests.

Roosts in termite nests were monitored with automatic transponder-readers (Kerth and König 1996) to identify individuals and specifically roost-makers, on infrared videorecordings. Group composition and body condition of males were determined for bats captured in groups from termite nests. Finally, the DNA of all captured individuals was analyzed to investigate relatedness and individual reproductive success of males.

\section{Methods}

Study site

Our main study site for fieldwork was on Barro Colorado Island (BCI) at the Barro Colorado Natural Monument (BCNM), Panama. This 1,560-ha island is located in Gatun Lake $\left(9^{\circ} 10^{\prime} \mathrm{N}, 79^{\circ} 150^{\prime} \mathrm{W}\right)$, and borders the Panama Canal in central Panama. BCNM is covered with semi-deciduous tropical lowland rainforest (Foster and Brokaw 1982). Rainfall averages 2,600 mm per year, and about $90 \%$ of rain falls from mid-April to December (Windsor 1990).

A second study site was located in the 22,000-ha Soberania National Park (Soberania; $9^{\circ} 07^{\prime} \mathrm{N}, 79^{\circ} 42^{\prime}$ ) and was covered with similar vegetation as the BCNM. Soberania stretches along the mainland border of the Panama Canal, east of BCI.

\section{Study organism}

L. silvicolum (formerly Tonatia silvicola; Lee et al. 2002) is a medium-sized, gleaning, insectivorous bat with an average mass of $30 \mathrm{~g}$ (this study), which occurs in lowland rainforests from southern Mexico to northern Brazil (Reid 1997). At our study sites, and especially on BCI, it is one of the more common bat species according to long-term capture records (Kalko et al. 1996). Few aspects of its ecology and behavior have been studied. Previous telemetry studies found average individual home ranges of 20.7 ha (Bockholdt 1998; Kalko et al. 1999). The species uses a hang-and-wait foraging strategy, catching its large arthropod prey during short flights followed by landing on the ground, after detecting prey by passive listening (Kalko et al. 1999). Little is known about the species' reproductive cycle other than that females give birth to a single offspring once and sometimes twice a year (Reid 1997).

\section{Capture and marking of individuals}

We captured L. silvicolum between March 2000 and June 2003, either in mistnets along forest trails at night, or directly from roosts during the day. We also captured bats 
from termite nests when pups were present and occasionally upon discovery of a roost. We used a hand net fashioned from a ring with mistnet material, and surrounded with rubber foam to protect the termite nest from damage. As roosts were, on average, $3.8 \mathrm{~m}$ above ground and could be as high as $10.5 \mathrm{~m}$ (Kalko et al., unpublished work), the trap was fastened to an extendable pole. Roosts were either found by visually searching the forest for excavated termite nests, or by radio-tracking bats (Kalko et al. 1999) that had previously been captured in nets or from roosts.

We sampled a small piece of patagial wing membrane for DNA extraction from all individuals using a 3-mm sterile biopsy punch (Stiefel, Germany). The resulting hole healed completely within 2-3 weeks (D.K.N. Dechmann, personal observation). Wing tissue was stored in $95 \%$ ethanol until extraction in the laboratory.

Because marking with necklaces or wing-bands had proven harmful to L. silvicolum and unsuitable for identification of animals on videotapes (Ueberschaer 1999), we used passive, subcutaneous transponders (pit-tags, EuroID. Weilerswist, Germany) to identify individual bats in order to determine roost-makers. Each transponder carries an individual code, which can be recorded with a hand-held reader or with a self-made antenna attached to an automatic reader (Kerth and König 1996). Most bats captured on BCI, except pups younger than 3 weeks, were marked with transponders before release. We attached automatic readers to hand-made antennas and placed them around the entrance of selected termite nests. This enabled us to identify and monitor bats without further handling or other disturbance.

\section{Morphology and reproductive status}

We determined sex and age of all captured individuals. Bats were aged as juvenile, subadult, or adult by the degree of ossification of the epiphyses of their finger-bones (Anthony 1988). Unfledged or very freshly fledged young were classified as pups. We then assessed the reproductive status of all adults. For females, we inspected the nipples and palpitated the belly for a fetus. We discriminated between four female reproductive states: non-reproductive, pregnant, lactating, and post-lactating (Racey 1988). For males, we measured testes size using calipers (length and width in millimeters) and considered only adult males with a testes width of $5 \mathrm{~mm}$ or more to be reproductively active. We determined the reproductive cycle, and calculated the percentage of reproductively active males and pregnant/lactating females for each month over the entire study period.

We measured body mass in grams (only non-pregnant females included), as well as lengths of forearm and tibia in millimeters of all adult animals to quantify differences among males and between the sexes. We analyzed data for males and females in a multivariate GLM (general linear model) after testing for normal distribution. We compared body-size measures of males captured at roosts alone or with other males, with those of males captured at roosts with at least one female in a GLM with body mass as a dependent factor and forearm length as a covariate.

\section{Group composition and behavior}

To determine group composition, we recorded number, sex, age, and reproductive status of bats each time we captured them from a termite nest. Whenever we were unable to capture all bats, we counted the number of escapees.

Transponder-reading antennas around cavity entrances recorded the identity and time of arrival and emergence of each marked bat. By following known bats on videotape, we assigned behaviors to individuals (see also Dechmann et al. 2004). We analyzed video-recordings from 2 roosts during 19 nights between 06.06.2002 and 03.06.2003 (CCD Camera IR-CCD VK-121, lens AO8Z1-5NDDCI 8/8$120 \mathrm{~mm}$, both Eneo, recorder GV-D1000 Portable DVCR Digital Video, Sony Europe, and custom-made infrared panel). We quantified the total number of hours that adult females, adult males, and subadults were present in the recordings, and the time each individual spent manipulating the nest to further enlarge the cavity or undo recent repair work by the termites.

\section{Genetic analyses}

We extracted DNA from skin samples using a salt chloroform method (Müllenbach et al. 1989). Afterwards, we screened all animals at 11 polymorphic microsatellite loci, 7 of which have been published previously (Dechmann et al. 2002; Table 1). Three new loci were added to one of the multiplex PCRs, in Dechmann et al. (2002), changing the protocol to the following: 6-plex [Tsi1Ca2 (new), Tsi1Ca3, Tsi3Ca2, Tsi3Ca9, Tsi4Ca2 (new), Tsi6Ca3 (new)]: $55^{\circ} \mathrm{C}$, 30 cycles, $2.5 \mu \mathrm{l}$ buffer $(10 \mathrm{x}), 1.5 \mu \mathrm{l} \mathrm{MgCl} 2$ (25 mM), $0.5 \mu \mathrm{l}$ dNTP $(10 \mathrm{~mm}), 0.5 \mu \mathrm{l}$ taq.polymerase and $1 \mu \mathrm{l}$ DNA (diluted 1:10). We added $0.6 \mu \mathrm{l} \mathrm{Tsi1Ca} 2$ and Tsi6Ca3 of both the $5^{\prime}$ and the $3^{\prime}$ primer. For Tsi4Ca2, we added $0.8 \mu \mathrm{l}$ each. Primer concentration was always $10 \mathrm{~mm}$. For other primers and the second multiplex, see Dechmann et al. (2002). An additional primer pair (locus AJA123) was obtained from Ortega et al. (2002). AJA123 was analyzed separately under the following conditions: $55^{\circ} \mathrm{C}, 35 \mathrm{cy}-$ cles, $1.5 \mu \mathrm{l}$ buffer (10x), $1.5 \mu \mathrm{lgCl}_{2}(25 \mathrm{~mm}), 0.3 \mu \mathrm{l}$ dNTP $(10 \mathrm{~mm}), 0.1 \mu \mathrm{l}$ taq.polymerase, $0.5 \mu \mathrm{l}$ of each primer (10 mM).

In the parentage analysis, we included only those pups for which we were able to predict at least one putative father. A predicted father was either captured together with the pup, or had been captured with the pup's mother previously in another nest. As in Slate et al. (2000), we used likelihood ratios, obtained with the program Cervus 2.0, to confirm parentage (Marshall et al. 1998).

Maternity of pups that were not attached to the nipples of their mothers at capture was assigned based on genetic 
Table 1 The 11 microsatellite loci used to assign maternity and paternity in this study. All except AJA123 (from Ortega et al. 2002; developed for Artibeus jamaicensis) were specially developed for L. silvicolum. Seven were previously published in Dechmann et al.
(2002): Tsi1Ca3, Tsi2Ca1, Tsi3Ca2, Tsi3Ca9, Tsi3Ca13, Tsi3Ca16, Tsi3Ca17 and three are first published here (Tsi1Ca2, Tsi4Ca2, Tsi6Ca3). Heterozygosities were calculated with Cervus 2.0 (Marshall et al. 1998)

\begin{tabular}{|c|c|c|c|c|c|c|c|c|}
\hline Locus & Primer sequence $\left(5^{\prime}-3^{\prime}\right)$ & $\begin{array}{l}\text { Annealing } \\
\text { temp. (C) }\end{array}$ & $\begin{array}{l}\text { Repeat } \\
\text { motif }\end{array}$ & $\begin{array}{l}\text { Locus } \\
\text { size (bp) }\end{array}$ & $\begin{array}{l}\text { No. of } \\
\text { alleles }\end{array}$ & $H_{\mathrm{E}}$ & $H_{\mathrm{O}}$ & $\begin{array}{l}\text { GenBank } \\
\text { accession no. }\end{array}$ \\
\hline Tsil1Ca2 & $\begin{array}{l}\text { CAAGGAATAATGTGTGTGTGCAT } \\
\text { TCCTGGTTTGGCAAGTGAT }\end{array}$ & 55 & $(\mathrm{TG})^{16}$ & $85-105$ & 10 & 0.795 & 0.769 & AY547505 \\
\hline Tsil1Ca3 & $\begin{array}{l}\text { TGCTTAGCTGATTAAGCCAGA } \\
\text { TGGGGTTATATGTTTTTATCTCTTCTT }\end{array}$ & 55 & $(\mathrm{GT})^{16}$ & $100-130$ & 10 & 0.756 & 0.769 & AF413027 \\
\hline Tsil2Ca1 & GTGCTCTTCCATGCACAGG & 60 & $\begin{array}{l}(\mathrm{CT})^{12}(\mathrm{CA})^{12} \\
(\mathrm{GA})(\mathrm{CA})^{2} \\
(\mathrm{TA})(\mathrm{CA})^{13}\end{array}$ & $115-160$ & 13 & 0.563 & 0.562 & AF413028 \\
\hline Tsil3Ca2 & $\begin{array}{l}\text { TGCTACACAGGTTGCGACTAC } \\
\text { GGAAATGGGAGGCAGATTAAG } \\
\text { TTCATCTCTAGATATTCAAAGG }\end{array}$ & 55 & $(\mathrm{CA})^{24}$ & $180-200$ & 11 & 0.841 & 0.828 & AF431029 \\
\hline Tsil3Ca9 & $\begin{array}{l}\text { TGGCACCACTTTCTTGTCAG } \\
\text { TGGTGGTGGTCACAGGAATC }\end{array}$ & 55 & $(\mathrm{GT})^{21}$ & $145-180$ & 9 & $\begin{array}{l}0.523 \\
0.496^{\mathrm{a}}\end{array}$ & $\begin{array}{l}0.305 \\
0.496^{\mathrm{a}}\end{array}$ & AF431030 \\
\hline Tsil3Ca13 & $\begin{array}{l}\text { ACСТTTCССТTCTCССТCAC } \\
\text { CAACTATTGACAGATGAATCCAAAC }\end{array}$ & 60 & $(\mathrm{TG})^{19}$ & $125-165$ & 10 & 0.716 & 0.717 & AF431031 \\
\hline Tsil3Ca16 & $\begin{array}{l}\text { ACCCTACTCATGTTCTCAGC } \\
\text { GCTACTAGTAATAACAGTGTGACAGC }\end{array}$ & 60 & $(\mathrm{TG})^{17}$ & $75-100$ & 11 & 0.793 & 0.809 & AF431032 \\
\hline Tsil3Ca17 & $\begin{array}{l}\text { AGAGCACTGGGCAAGGTAGG } \\
\text { GAGCTTCTTGAAGGTAAGGATCAG }\end{array}$ & 60 & $(\mathrm{CA})^{19}$ & $75-115$ & 14 & 0.793 & 0.809 & AF413033 \\
\hline Tsil4Ca2 & $\begin{array}{l}\text { TTACCCATGCAAGCAAACAC } \\
\text { TGTTTTGAATGGACCTGCTG }\end{array}$ & 55 & $(\mathrm{CA})^{17}$ & $105-115$ & 8 & 0.826 & 0.818 & AY547506 \\
\hline Tsil6Ca3 & $\begin{array}{l}\text { TGGAATGTGTCCTTACAATG } \\
\text { CTGATTGTGTGGAGCTGT }\end{array}$ & 55 & $(\mathrm{CA})^{20}$ & $120-160$ & 17 & 0.857 & 0.858 & AY547507 \\
\hline AJA123 & $\begin{array}{l}\text { GACCACTTTTCCTCCCATGAC } \\
\text { CCTGAGCTAATACTCCAGAGGAAG }\end{array}$ & 55 & $\begin{array}{l}(\mathrm{CA})^{1} \mathrm{~A}(\mathrm{CA})^{17} \\
\mathrm{CT}(\mathrm{CA})^{2}\end{array}$ & $225-255$ & 12 & 0.872 & 0.841 & AY099073 \\
\hline
\end{tabular}

${ }^{a}$ Heterozygosities for females only

data. Because the inclusion of maternal alleles allows more powerful determination of paternity, and because we expected to find mothers and dependent pups together in a nest, a lactating female captured together with a pup was deemed that pup's mother if there were no maternal allele mismatches. Whenever individuals had escaped, we assigned the mother with Cervus, including only adult females that had previously been captured in the same roost. We only accepted females as mothers with a positive LOD (logarithm of likelihood ratio), and if the DNA mismatched at no more than one locus (Marshall et al. 1998).

Similarly, when assigning fathers, we accepted only those with the highest LOD with the pup in question, again allowing for one mismatching allele. Simulations required for the calculation of the significance of paternity assignments were run separately for mothers and fathers, with 10,000 permutations, a typing error of 0.01 , and a sampling rate of $50 \%$ (assessed by recapture rates). Confidence levels were set at $80 \%$ and $95 \%$. A file including predicted fathers from all roosts were used in the Cervus analysis for all tested pups (BCI: 13 males, Soberania: 6 males).

We repeated the analysis for the Barro Colorado Island population, this time including all adult males and pups from $\mathrm{BCI}$, to verify our predictions concerning potential fathers. Here we additionally tried to assign fathers to those five pups that had been captured in roosts containing no males (see Results) and for which no father could be predicted.

We compared the degree of relatedness of males with pups captured in the same nest and with pups captured in other nests, to assess the relative reproductive success of males in their own nest. Here, we again included all pups, even if their father was unknown or not currently in the same roost. We calculated pairwise relatedness ratios with the program Relatedness 5.0.8. (Queller and Goodnight 1989) for all males in whose nest pups had been captured, with all pups captured in other nests. In a paired $t$-test, we then compared average relatedness of each male to pups in the same nest with that to pups from other nests.

\section{Statistical analyses}

We did all statistical analyses, except for those integrated into Cervus and Relatedness, with SPSS 11 (SPSS, Chicago). All data were tested for normal distribution with the Kolmogorov-Smirnov method. The significance level was $5 \%$. 


\section{Results}

Number of roosts and animals

We captured 388 bats, of which 51 were pups. Thirty-four of the pups were too young to be marked with transponders and only a wing biopsy for DNA analysis was obtained from them. Thirty individuals, which were captured in Soberania and parts of the BCNM other than BCI, were sampled for DNA but not marked, as recapture efforts at those sites were low. About $50 \%$ of the captured animals were already marked during the final field season from March to June 2003.

We captured bats from a total of 34 excavated termite nests. We found 15 roosts by visual searching and 19 by radio-tracking previously captured bats. Two of these roosts ("Kodak" and "Donato") were monitored with transponderreading antennas and video-recordings.

Morphology and reproductive status

We captured and analyzed data for $14.6 \pm 10.8$ females and $10.6 \pm 4.2$ males per month. Females had two yearly pregnancy peaks. The main peak was in March/April and a second one occurred in August/September (Fig. 2). Each of these was followed by an increase in lactating females. However, this increase was much more distinct after the first pregnancy peak. Males also showed two periods of increased reproductive activity, the first starting during late pregnancy at the end of the dry season (February/March), peaking in April. The percentage of males with enlarged testes then slowly decreased and peaked again at the height of the rainy season (November) after females had given birth for the second time.

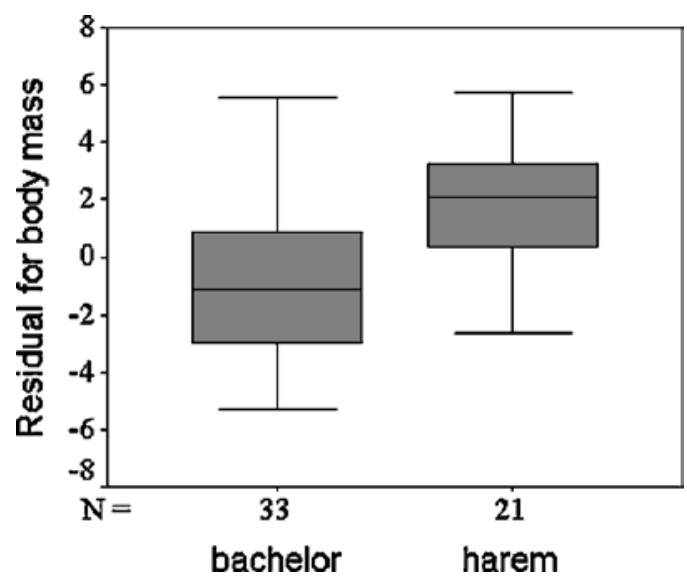

Fig. 3 Residuals of mean body mass corrected for forearm length of male Lophostoma silvicolum captured with females ("harem": $33.2 \pm 2.8 \mathrm{~g}$ ) or without females ("bachelor": $31.1 \pm 2.6 \mathrm{~g}$ ) from excavated termite nests

Distinct dimorphism between the sexes was significant in all three parameters we investigated, with males being heavier and larger than females (Table 2).

We also found significant variation in physical condition among males. Males captured together with females were in better condition (mass corrected for forearm-length, type III sum of squares $=284.30, F_{20}=2.38, P=0.013$; Fig. 3 ) than males captured without females. Harem males, including the two males from the roosts observed with transponder antennas, never reversed their status during our study (seven males recaptured between one and three times, not including logger data). However, three single males and one male from a bachelor roost were later captured with females. Multiple captures of the same individuals were included to control for potential variation in body mass due to a change of status (harem male or not) or season.
Fig. 2 Reproductive state of 127 adult male and 175 adult female Lophostoma silvicolum on $\mathrm{BCI}$
Table 2 Body mass, and lengths of forearm and tibia of male and female L. silvicolum. Results of a multivariate GLM, testing the influence of sex on those variables (type III of squares). All interactions were significant $(P<0.001)$

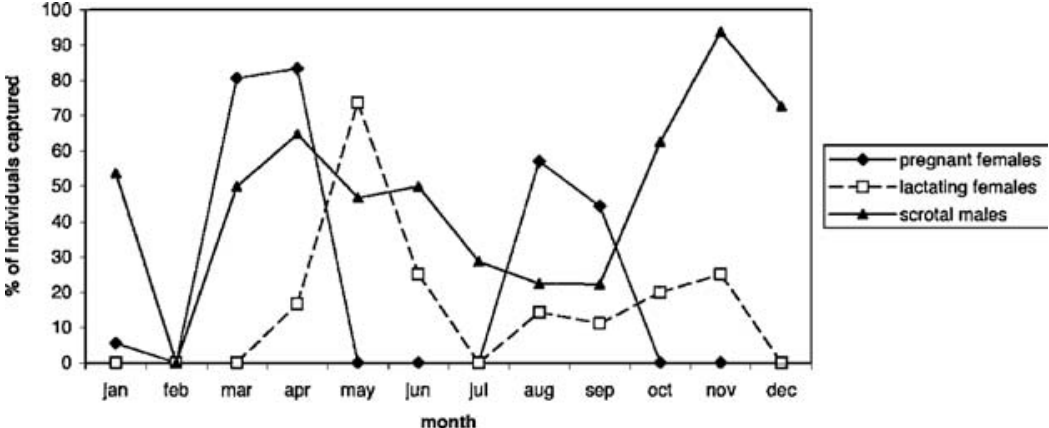

\begin{tabular}{llllllll}
\hline & Sex & $n$ & Mean & SE & GLM & \\
\cline { 5 - 7 } & & & & & Sum of squares & $F_{1,118}$ & $P$ \\
\hline Mass & $\mathrm{m}$ & 136 & $31.9 \mathrm{~g}$ & 0.37 & & & \\
& $\mathrm{f}$ & 138 & $29.8 \mathrm{~g}$ & 0.27 & 101.77 & 9.21 & 0.003 \\
Forearm & $\mathrm{m}$ & 130 & $52.7 \mathrm{~mm}$ & 0.11 & & & \\
& $\mathrm{f}$ & 138 & $52.1 \mathrm{~mm}$ & 0.12 & 26.61 & 14.79 & $<0.001$ \\
& $\mathrm{~m}$ & 55 & $28.5 \mathrm{~mm}$ & 0.15 & & & \\
& $\mathrm{f}$ & 65 & $27.9 \mathrm{~mm}$ & 0.10 & 9.59 & 7.91 & 0.006 \\
\hline
\end{tabular}


Table 3 Composition of groups of L. silvicolum, captured from excavated termite nests. Categories: number of captures per grouptype; total number of males; mean number of females; mean number of subadults of both sexes; mean number of pups and number of escaped individuals. Range of number of captured individuals given in parentheses where appropriate

\begin{tabular}{lllllll}
\hline Group type & No. caps. & Ad. males & Mean no. fem. & Mean no. subad. & Mean no. pups & Escapes \\
\hline Incomplete harem & 34 & $0-1$ & $1.6(0-5)$ & $0.4(0-2)$ & $1.1(0-5)$ & $\geq 1$ \\
Complete harem & 11 & 1 & $2.1(0-6)$ & $0.5(0-2)$ & $0.5(0-3)$ & 0 \\
Solitary males & 8 & 1 & 0 & 0 & 0 & 0 \\
All-female & 4 & 0 & $3.7(1-8)$ & 0 & 0 & $1.2(0-4)$ \\
Multi-male & 4 & $3(2-4)$ & $0.7(0-3)$ & 0 & $0.5(0-2)$ & $\geq 0$ \\
\hline
\end{tabular}

In a second step, we analyzed males captured alone (included in males without females above) separately from those captured in male groups. Single males were of intermediate mass $(32.1 \pm 2.3 \mathrm{~g}, n=7)$. This difference was not significant from either males captured with females, or males captured in male groups (data not shown).

\section{Group size and social structure}

Group composition was determined based on 61 capture events from 34 excavated termite nests (Table 3 ). We made up to four capture attempts per nest. Time between captures at the same roost ranged from 5 days to 19 months. Females often left a roost after capture and a second capture attempt was only made soon after the first one, if many animals had escaped. Usually, we only captured at a nest once each reproductive season. Most of the groups consisted of one adult male, one to several adult or subadult females, and up to five juveniles. One group also contained one subadult male. Composition of large groups was more difficult to determine, as animals were more likely to escape from them. The largest group including juveniles comprised 12 animals, 8 of which were captured. We encountered eight single males and three larger groups with a maximum of four adult males. One of the latter groups also contained three lactating females and their pups. Four groups of females containing no male were captured. Three of them were captured within 10 days of each other, in June 2003.

\section{Behavior}

We covered all phases of the reproductive cycle with the 19 nights that we videotaped (Kodak: $n=8$; Donato: $n=11$ ). Adult females $(n=6)$ were observed for $78 \mathrm{~h} 20 \mathrm{~min}$, adult males ( $n=2$, one in each nest) for $62 \mathrm{~h} 35 \mathrm{~min}$, and subadults (one male and one female) for $30 \mathrm{~h} 5 \mathrm{~min}$. Two small pups were also present in Donato in June 2003. They were not yet able to fly and stayed in the roost until one mother permanently left Donato, taking the pup with her. The pups' presence on the recordings was not quantified. Nest modification occurred during 5 nights and lasted between 2 and 35 min per night. Males enlarged or restored the cavities using their teeth, reinforcing their biting power by pushing themselves off the cavity walls with their forearms. We were able to identify the individual working on the nest in all cases. Whenever several bats were present, all of them were visible and thus no events of nest modification were overlooked. Both adult males were observed modifying the nest they inhabited (nest 1: 1 out of 8 nights, nest 2: 4 out of 11 nights). However, they only did so when no other bats were present. Females, subadults, and pups were never observed modifying the nest, although more individuals were filmed. During several nights without nest modification, the male was never alone in the nest, especially when females had pups and frequently returned to feed them.

\section{Genetic analysis}

We excluded Tsi3Ca9 from the dataset as this locus turned out to be x-linked. Values of observed heterozygosity $\left(H_{\mathrm{O}}\right)$ of the remaining ten loci agreed with expected heterozygosity $\left(H_{\mathrm{E}}\right.$; Table 1$)$.

Our data on the reproductive cycle and group composition suggest a post-partum estrus in L. silvicolum. Thus, the adult male of the nest where a female last gave birth would be the most likely father of her current pup. Hence, we only analyzed pups if we had captured a male in the same roost, or pups of females that had roosted with a known male during the previous reproductive season. These conditions were met in 12 of the 34 roosts (1-3 capture events during different reproductive seasons per roost; pups included in the analysis: BCI: $n=36$; Soberania: $n=10$ ).

We assigned 33 of the 46 pups to putative mothers with zero $(n=32)$ or 1 mismatch $(n=1)$, and used these candidate mothers in our assignment of fathers. In cases where no bats had escaped at capture, each pup could be assigned to one of the present lactating females. For all pups, we predicted between one and three potential fathers (total number of males tested on BCI: $n=13$; in Soberania: $n=6$ ). A predicted father turned out to be the genetic father in 21 of the 46 cases (all with zero mismatches). This corresponds to an average reproductive success of $46 \%$ of the predicted males. Average LOD for assignment of mothers was $4.27 \pm 2.1$ and for fathers $6.16 \pm 2.4$.

We know very little about the nest-switching behavior of females. Seventeen of the 21 pups for which a father was successfully predicted, were assigned to the current nest male. The remaining five mothers had moved from a known roost since the last reproductive season and the male of that previous roost had sired their pup. Only one female was captured in different nests during two successive reproductive seasons, but neither of the two harem males had sired her pup. Most females were either 
captured the first time when they were captured with the pup $(n=24)$, or they had moved roosts more than one reproductive season ago $(n=5)$.

The second Cervus analysis included 104 adult males and all 41 pups from BCI. For 13 of the 16 BCI pups where a father had been predicted and confirmed before, the most-likely father assigned by Cervus was the same as in the previous analysis (average $\mathrm{LOD}=5.72 \pm 2.50$ ). In two other cases males assigned with a higher LOD had at least one mismatch with the pup in question while the male currently roosting with the pup's mother had none. In the third case, the assignment by our second analysis resulted in another father than the one predicted from capture data. Only four pups were assigned to unpredicted males, one of which was a known harem male from another roost, without mismatches. All other assigned father-offspring pairs had between one and four mismatches, although the average LOD was still relatively high $(3.47 \pm 1.18)$. The social status (harem or bachelor male) of unpredicted males during the time the pups were born or conceived is unknown because they had been captured in mistnets and not directly from a roost.

We calculated average degrees of relatedness between males and pups for the 12 males that cohabited with pups when captured from a roost. We expected high degrees of relatedness if the mothers of those pups had remained in or returned to the same site in which they were last inseminated. We then computed average relatedness between each of the same 12 males and any pups not found in that male's modified nest. Males were significantly more closely related with pups caught in the same roost than with pups from other roosts (same roost: $r=0.25 \pm 0.24$; other roost: $r=0.01 \pm 0.05 ; t=3.64, d f=11, P=0.004)$. Males sired between none and four out of five pups in their own roost per reproductive season.

\section{Discussion}

Mating strategies are strongly influenced by the amount of investment in courtship and parental care by the mating partners (Emlen and Oring 1977). One form of investment is the making of shelters, which are crucial for the survival and reproduction of many animals. Our results indicate that male $L$. silvicolum excavate active termite nests, which are then used as roosts. Males consequently gain reproductive success by mating with the females that join them in their roosts.

\section{Reproductive cycle}

In order to understand mating strategies, it is important to know the reproductive cycle of a species. In species, where estrus is frequent or non-seasonal, males should attempt to stay near females and ready to mate. In contrast, when there is a distinct female reproductive season, the sexes may segregate during most of the year. For example, many male ungulates join females only shortly before the on- set of the mating season (Ruckstuhl and Neuhaus 2002). Our data indicate that, like several other species of tropical bats (Racey and Entwistle 2000), L. silvicolum exhibits bimodal polyestry with post-partum estrus, in which females become receptive shortly after parturition.

\section{Evidence for resource-defense polygyny}

Only males modified nest cavities, thus presumably creating a roosting resource for females. While we cannot exclude the possibility that males occasionally also usurp and take over previously excavated roosts from other males, the composition of $95 \%$ of the roosting groups provides additional evidence for resource-defense polygyny. Most groups were single male-multifemale groups, henceforth called harems. The three multimale groups were probably associations of bachelors. Bachelor groups are also known from other harem-forming bats such as Phyllostomus hastatus (McCracken and Bradbury 1981) and Artibeus jamaicensis (Kunz et al. 1983; Ortega and Arita 2000). One of the bachelor groups contained three females we had captured shortly before in another roost. This may have caused those females to join a bachelor group. The significance of the four all-female groups remains unclear.

While our results suggest that males excavate termite nests to attract females and achieve matings, living in active termite nests may not be equally beneficial for males and females. The evolution of such an unusual roost-choice is only possible if the interests of both sexes are met. Shared benefits may be the same as for birds living in nests of social insects: protection from predators through the hardness and shape of the nest, or indirect defense by commensal ants (Brightsmith 2000; Hansell and Deeming 2002), which are commonly found in nests of Nasutitermes corniger, inhabited by L. silvicolum (D.K.N. Dechmann, unpublished data). But there may also be sex-specific benefits of roosting in active termite nests.

\section{Male point of view}

Males must invest the time and energy required to excavate hard nests. The fact that males are alone when excavating or maintaining a cavity may indicate that they allocate time other group members spend foraging. $N$. corniger usually begins to repair nests soon after damage is inflicted and cavities were often filled a few days or weeks after bats deserted a roost in an active nest (D.K.N. Dechmann, personal observation). Thus, constant maintenance and presence by the male seem necessary even after the completion of the cavity. This is supported by the observation that presence of bats is associated with the amount of nest material collected underneath termite nests with completed cavities (Ueberschaer 1999). Few other bats, one of them the paleotropical Cynopterus sphinx (Balasingh et al. 1995; Storz and Kunz 1999), seem to invest a comparable effort into roost-making. Males of this species are also larger than females in the part of their range where the species is more polygynous (Storz et al. 2001a). 
Although relatively rare in bats (Ralls 1977), larger size of males is considered a sexually selected trait and has a strong influence on fitness in mammals (Clutton-Brock 1988; McElligott et al. 2001). Sexual dimorphism is typical for polygynous mammals and may occur among haremforming bats with high male investment. Phyllostomus hastatus, for example, lives in harems year round and harem maintenance appears to be costly for males. Male P. hastatus are larger than females (McCracken and Bradbury 1981; Kunz et al. 1998). In contrast, males of the tentmaking Ectophylla alba are not larger than females, and harems are only formed during the breeding season (Brooke 1990). However, in the spotted-winged fruit bat Balionycteris maculata, which also sometimes inhabits excavated ant or termite nests, males are smaller than females while of the same mass (Hodgkison et al. 2003). Actual roostmaking has not been observed in this species, but it is most likely done by males. It is unknown if roost-making in this species is less costly or other selective forces have caused larger size of females, as in populations of C. sphinx (Storz et al. 2001a). But we suggest that sexual dimorphism is a strong indicator for high male investment in L. silvicolum, regardless of whether it is a sexually selected trait or an indicator of a male's higher ability to invest in roost-making and/or harem maintenance.

A good physical condition may be necessary for both making and defense of a cavity. Males of polygynous mammals, such as fallow deer, only gain additional body mass before the breeding season (McElligott et al. 2003). In contrast, male L. silvicolum with harems were heavier than unsuccessful males throughout the year. We cannot exclude the possibility that this difference in physical condition is an age effect as in other species (Kunz et al. 1983; Storz et al. 2000). Regardless of age, males that did monopolize a nest, but did not manage to attract females, were of intermediate mass. This seems to indicate that the females prefer larger males, although cues not obvious to us may have led females to choose appropriate nests rather than males.

Is male reproductive success high enough to justify nestmaking and maintenance? Reproductive success in harems has been assessed in a few species of polygynous bats. In Saccopteryx bilineata, males defend harems and court females by hovering displays (Bradbury and Vehrencamp 1976; Voigt and von Helversen 1999). In this species, males sire $29 \%$ of the pups in their harem (Heckel et al. 1999). In other species, this value averages around $60 \%$ but can range up to $100 \%$ in individual harems (Storz et al. 2001b; Ortega et al. 2003). In comparison, male birds, such as tree swallows, remain socially monogamous in spite of $70 \%$ or more extra-pair copulations by the females (Kempenaers et al. 1999). Thus, our estimate of $46 \%$ falls well within the range reported from other species. In addition, we may have underestimated individual male reproductive success. If we had known more previous harem-males of mothers, this would have allowed us to predict and test more potential fathers of pups.

As in leaf-modifying bats (Lewis 1995), the nature of their chosen roosts forces $L$. silvicolum to be flexible.
Termite colonies may die or be damaged by predators, forcing the females to find a new shelter, while the male must excavate another nest. Due to post-partum estrus, females may also switch termite nests after mating and give birth in the roost of a male that is not the father of their pup. However, we found that when we captured mothers, they were still roosting with the fathers we were able to assign to their pups. This was true in all except five cases, where the assigned father was the male the mother had roosted with previously. This means that females often remain faithful to a roost or male for several breeding seasons. At the same time, sheltering another male's pup may not incur additional costs, if the nest-holder can sire the mother's next offspring. Reproductive success of male $C$. sphinx depends on colony structure during the previous post-partum estrus rather than current parturition (Storz et al. 2001b), and the same may be true for male L. silvicolum. We show that relatedness of males with pups in their nest is high, indicating that they mate with the females that roost with them, thus justifying roost-making. Providing suitable roosts may be a strategy of males to motivate females to remain with them and thus gain access to matings.

\section{Female point of view}

In mammals, females are usually the sex that chooses highquality mating partners. A safe and otherwise suitable shelter, in which to give birth to their young and rear them, is also important, and may be an indicator for male quality in L. silvicolum. Here, roost temperature may play a crucial role. Temperatures in active excavated termite nests are higher than in inactive ones, or in tree holes, occupied by closely related bat species (Dechmann et al. 2004). Little is known about the use of torpor by phyllostomids (Speakman and Thomas 2003). But as torpor slows milk production, lactating females should be selected not to reduce their metabolism (Wilde et al. 1999). In addition, young bats are altricial and can thermoregulate only to a limited extent. A cool environment can slow down postnatal growth (Kunz and Hood 2000). As a behavioral response, maternity colonies of bats often roost in warmer places than non-reproductive individuals (Kunz 1982). The higher temperature in the termite nests may be important at least for females and their offspring, and may have contributed to the roost choice of this species (Dechmann et al. 2004). However, not only reproductive females, but also all other individuals, including bachelor males, live in termite nests all year. This indicates that termite nests may be advantageous for all members of this species, and further investigation of the benefits of roosts in termite nests is needed.

The evolution of an external trait, e.g. a shelter made by a male, can be significantly enhanced if it makes finding males easier for the females (Andersson 1994). Some of the termite nests we found contained only single males. This indicates that it is not sufficient for a male to excavate or take over a termite nest to attract females. In order to select a male and/or the cavity offered by him, females may need to find and visit several nests. This may be facilitated if 
termite nests are more conspicuous than other roosts, such as tree cavities.

In conclusion, we suggest that living in excavated termite nests is beneficial for both male and female L. silvicolum, albeit at least partially for different reasons. This particular roost choice, as well as the fact that only males construct the cavities, are closely connected with the mating system of this bat and may not have evolved independently. Future research on metabolic costs and benefits should allow us to better understand the role of roost-making. It may also help us to learn about the special adaptations that were necessary for the development of this trait, and may answer the question of why roost-making is not more common in bats.

Acknowledgements This project was supported by grants from the Roche Research Foundation and the ZUNIV-Fonds zur Förderung des Akademischen Nachwuchses (FAN). The Julius-Klaus-Stiftung (Zürich) and the Brachet Foundation (Belgium) financed the genetic analyses. We are grateful to the Smithsonian Tropical Research Institute (STRI) and the National Authority for the Environment (ANAM) for research permits, which ensured that all work was carried out in concordance with current Panamanian laws. We also want to thank the staff of Barro Colorado Island, especially the game wardens, for their support. The following people helped with fieldwork, development of equipment and/or with data analysis: A. Beck, M. Demir, S. Heucke, M. Kalka, J. Mandel, F. Neuhäuser-Wespy, K. and K. Safi, A. Schulz, M. Weinbeer, S. Wetterich, and especially A. Lang, S. Spehn, and C. Weise. Special thanks for help with the genetic work are owed to J. Garbely and T. Garner. We also thank J. Bradbury, L. di Iorio, T. Kunz, G. McCracken, A. McElligott, G. Wilkinson, and an anonymous reviewer for valuable comments on the manuscript.

\section{References}

Andersson M (1994) Sexual selection. Princeton University Press, Princeton, NJ

Anthony ELP (1988) Age determination in bats. In: Kunz TH (ed) Ecological and behavioral methods for the study of bats. Smithsonian Institution, Washington, DC, pp 47-58

Balasingh J, Koilraj J, Kunz TH (1995) Tent construction by the short-nosed fruit bat Cynopterus Sphinx (Chiroptera, Pteropodidae) in Southern India. Ethology 100:210-229

Bhat HR, Kunz TH (1995) Altered flower fruit clusters of the kitul palm used as roosts by the short-nosed fruit bat, Cynopterus Sphinx (Chiroptera, Pteropodidae). J Zool 235:597-604

Bockholdt C (1998) Hangplatzwahl, Aktivitätsrhythmik und Aktionsraum der neotropischen Fledermaus Tonatia silvicola (D’Orbigny, 1836). University of Freiburg

Bradbury JW, Vehrencamp SL (1976) Social organization and foraging in emballonurid bats. Behav Ecol Sociobiol 2:19-29

Brightsmith DJ (2000) Use of arboreal termitaria by nesting birds in the Peruvian Amazon. Condor 102:529-538

Brooke AP (1990) Tent selection, roosting ecology and socialorganization of the tent-making bat, Ectophylla alba, in Costa-Rica. J Zool 221:11-19

Clutton-Brock TH (1988) Reproductive success. University of Chicago Press, London

Clutton-Brock TH (1989) Mammalian mating systems. Proc R Soc Lond B 236:339-372

Collias NE (1964) The evolution of nests and nest-building in birds. Am Zool 4:175-190

Dawkins R (1976) The selfish gene. Oxford University Press, Oxford

Dawkins R (1999) The extended phenotype: the long reach of the gene, 2nd edn. Oxford University Press, Oxford

Dechmann DKN, Garbely E, Kerth G, Garner TWJ (2002) Highly polymorphic microsatellites for the study of the round-eared bat, Tonatia silvicola (d'Orbigny). Conserv Gen 3:455-458
Dechmann DKN, Kalko EKV, Kerth G (2004) Ecology of an exceptional roost: energetic benefits could explain why the bat Lophostoma silvicolum roosts in active termite nests. Evol Ecol Res 6:1037-1050

Dietz HF, Snyder TE (1924) Biological notes on the termites of the canal zone and adjoining parts of the republic of Panama. J Agric Res 26:279-302

Emlen ST, Oring LW (1977) Ecology, sexual selection, and evolution of mating systems. Science 197:215-223

Foster RB, Brokaw NVL (1982) Structure and history of the vegetation of Barro Colorado Island. In: Leigh EG Jr, Rand AS, Windsor DM (eds) The ecology of a tropical forest. Smithsonian Institution, Washington DC, pp 151-172

Hansell MH (1984) Animal architecture and building behaviour. Longman, London

Hansell MH, Deeming DC (2002) Location, structure and function of incubation sites. In: Deeming DC (ed) Avian incubation. Oxford University Press, Oxford, pp 8-27

Heckel G, Voigt CC, Mayer F, Von Helversen O (1999) Extraharem paternity in the white-lined bat Saccopteryx bilineata (Emballonuridae). Behaviour 136:1173-1185

Hodgkison R, Balding ST, Akbar Z, Kunz TH (2003) Roosting ecology and social organization of the spotted-winged fruit bat, Balionycteris maculata (Chiroptera : Pteropodidae), in a Malaysian lowland dipterocarp forest. J Trop Ecol 19:667676

Kalko EKV, Handley CO, Handley D (1996) Organization, diversity, and long-term dynamics of a Neotropical bat community. In: Cody ML, Smallwood JA (eds) Long-term studies of vertebrate communities. Academic, San Diego, pp 503-553

Kalko EKV, Friemel D, Handley CO, Schnitzler HU (1999) Roosting and foraging behavior of two Neotropical gleaning bats, Tonatia silvicola and Trachops cirrhosus (Phyllostomidae). Biotropica 31:344-353

Kempenaers B, Congdon B, Boag P, Robertson RJ (1999) Extrapair paternity and egg hatchability in tree swallows: evidence for the genetic compatibility hypothesis? Behav Ecol 10:304-311

Kerth G, König B (1996) Transponder and an infrared-videocamera as methods used in a fieldstudy on the social behaviour of Bechstein's bat (Myotis bechsteinii). Myotis 34:27-34

Kleiman DG, Malcolm JR (1981) The evolution of male parental investment in mammals. In: Gubernick DJ, Klopfer PH (eds) Parental care in mammals. Plenum, New York, pp 347-387

Kunz TH (1982) Roosting ecology of bats. In: Kunz T (ed) Ecology of bats. Plenum, New York, pp 1-55

Kunz TH, Hood WR (2000) Parental care and postnatal growth in the Chiroptera. In: Crichton EG, Krutzsch PH (eds) Reproductive biology of bats. Academic, London, pp 415-454

Kunz TH, Lumsden LF (2003) Ecology of cavity and foliage roosting bats. In: Kunz TH, Fenton MB (eds) Bat ecology, 1st edn. University of Chicago Press, Chicago, pp 3-90

Kunz TH, August PV, Burnett CD (1983) Harem social-organization in cave roosting Artibeus jamaicensis (Chiroptera, Phyllostomidae). Biotropica 15:133-138

Kunz TH, Robson SK, Nagy KA (1998) Economy of harem maintenance in the greater spear-nosed bat, Phyllostomus hastatus. J Mammal 79:631-642

Lee TE, Hoofer SR, Van Den Bussche RA (2002) Molecular phylogenetics and taxonomic revision of the genus Tonatia (Chiroptera: Phyllostomidae). J Mammal 83:49-57

Lewis SE (1995) Roost fidelity of bats-a review. J Mammal 76:481-496

Marshall TC, Slate J, Kruuk LEB, Pemberton JM (1998) Statistical confidence for likelihood-based paternity inference in natural populations. Mol Ecol 7:639-655

McCracken GF, Bradbury JW (1981) Social organization and kinship in the polygynous bat Phyllostomus hastatus. Behav Ecol Sociobiol 8:11-34

McElligott AG, Gammell MP, Harty HC, Paini DR, Murphy DT, Walsh JT, Hayden TJ (2001) Sexual size dimorphism in fallow deer (Dama dama): do larger heavier males gain greater mating success? Behav Ecol Sociobiol 49:266-272 
McElligott AG, Naulty F, Clarke WV, Hayden TJ (2003) The somatic cost of reproduction: what determines reproductive effort in prime-aged fallow bucks? Evol Ecol Res 5:1239-1250

Morrison DW, Morrison SH (1981) Economics of harem maintenance by a Neotropical bat. Ecology 62:864-866

Müllenbach R, Lagoda PJL, Welter C (1989) An efficient salt chloroform extraction method of DNA from blood and tissues. Trends Genet 5:391

Ortega J, Arita HT (2000) Defence of females by dominant males of Artibeus jamaicensis (Chiroptera: Phyllostomidae). Ethology 106:395-407

Ortega J, Maldonado JE, Arita HT, Wilkinson GS, Fleischer RC (2002) Characterization of microsatellite loci in the Jamaican fruit-eating bat Artibeus jamaicensis and crossspecies amplification. Mol Ecol Notes 2:462-464

Ortega J, Maldonado JE, Wilkinson GS, Arita HT, Fleischer RC (2003) Male dominance, paternity, and relatedness in the Jamaican fruit-eating bat (Artibeus jamaicensis). Mol Ecol 12:2409-2415

Queller DC, Goodnight KF (1989) Estimating relatedness using genetic-markers. Evolution 43:258-275

Racey PA (1988) Reproductive assessment in bats. In: Kunz TH (ed) Ecological and behavioral methods for the study of bats. Smithsonian Institution Press, Washington, DC, pp 277-302

Racey PA, Entwistle AC (2000) Life-history and reproductive strategies of bats. In: Crichton EG, Krutzsch PH (eds) Reproductive biology of bats. Academic, London, pp 364-401

Ralls K (1977) Sexual dimorphism in mammals-avian models and unanswered questions. Am Nat 111:917-938

Reid FA (1997) A field guide to the mammals of Central America and Southeast Mexico. Oxford University Press, New York

Ruckstuhl KE, Neuhaus P (2002) Sexual segregation in ungulates: a comparative test of three hypotheses. Biol Rev 77:77-96
Slate J, Marshall T, Pemberton J (2000) A retrospective assessment of the accuracy of the paternity inference program CERVUS. Mol Ecol 9:801-808

Speakman JR, Thomas DW (2003) Physiological ecology and energetics of bats. In: Kunz TH, Fenton MB (eds) Bat ecology, 1 st edn. University of Chicago Press, Chicago, pp 430 492

Storz JF, Kunz TH (1999) Cynopterus sphinx. Mamm Species 613:1-8

Storz JF, Bhat HR, Kunz TH (2000) Social structure of a polygynous tent-making bat, Cynopterus sphinx (Megachiroptera). J Zool 251:151-165

Storz JF, Balasingh J, Bhat HR, Nathan PT, Doss DPS, Prakash AA, Kunz TH (2001a) Clinal variation in body size and sexual dimorphism in an Indian fruit bat, Cynopterus sphinx (Chiroptera: Pteropodidae). Biol J Linn Soc 72:17-31

Storz JF, Bhat HR, Kunz TH (2001b) Genetic consequences of polygyny and social structure in an Indian fruit bat, Cynopterus sphinx. II. Variance in male mating success and effective population size. Evolution 55:1224-1232

Ueberschaer K (1999) Untersuchung zur Hangplatzökologie der neotropischen Fledermaus Tonatia silvicola unter Berücksichtigung der Sozialstruktur und des Reproduktionsstatus. University of Würzburg

Voigt CC, von Helversen O (1999) Storage and display of odour by male Saccopteryx bilineata (Chiroptera, Emballonuridae). Behav Ecol Sociobiol 47:29-40

Wilde CJ, Knight CR, Racey PA (1999) Influence of torpor on milk protein composition and secretion in lactating bats. J Exp Zool 284:35-41

Windsor DM (1990) Climate and moisture variability in a tropical forest: long-term records from Barro Colorado Island, Panama. Smithson Contrib Earth Sci 29:1-145 